\title{
New reports of Vaucheria species (Vaucheriales, Xanthophyceae, Heterokontophyta) from the Czech Republic
}

\author{
Katarína NemJovÁ ${ }^{1)} \&$ Veronika KaUfNEROVÁ ${ }^{2)}$ \\ ${ }^{1)}$ Department of Botany, Faculty of Science, Charles University of Prague, Benátská 2, CZ-128 01 Prague; Czech \\ Republic; e-mail: nemjova@natur.cuni.cz \\ ${ }^{2)}$ Department of Biology, Faculty of Education, University of West Bohemia, Klatovská 51, CZ-30619 Plzeñ, Czech \\ Republic; e-mail: veronika_kaufnerova@atlas.cz
}

\begin{abstract}
Several Vaucheria species from the Czech Republic were collected and identified, including V. borealis HiRn, $V$. hercyniana RIETH and $V$. woroniniana HeERING for the first time from the Czech Republic. Three other species, V. terrestris (VAucher) LyngB., V. sessilis (VAucher) DC. and V. geminata (VAucher) DC. were also recorded.
\end{abstract}

Key words: Vaucheria borealis, V. sessilis, V. hercyniana, V. terrestris, V. geminata, V. woroniniana, algal floristics, Xanthophyceae, Czech Republic

\section{Introduction}

The genus Vaucheria DC. belongs to Vaucheriales (Xanthophyceae) (PotTer et al. 1997), but it was earlier referred to Chlorophyceae (e.g. PASCHER 1903, Houppagh 1930). Rieth (1980) lists 32 species from Europe, many of which have worldwide distributions. Representatives occur in freshwater, brackish and terrestrial ecosystems (RIETH 1980, Johnson \& MERRIT 2002). Terrestrial species mostly prefer shaded and moist places, like in forest road ditches, in pools and on river and pond margins often appearing as green felt carpets (RIETH 1980, EtTL \& GäRTNER 1995).

Siphonous, multinucleate tubes are filledup with huge vacuoles and parietal, disc-shaped chloroplasts, usually without pyrenoid. The tubes are attached to the substrate by colourless rhizoids (EtTL \& GÄRTNER 1995). Members of the genus propagate asexually by synzoospores, aplanospores and akinetes, whereas sexual reproduction takes place by oogamy. Individual species could be dioecious or monoecious and the reproductive structures could be on the same short stalk (gametophore), or individually on the tube. Traditional classification of the species is mostly based on morphology of these sexual reproductive structures (RIETH 1980). Recent molecular phylogenetic analysis corresponds with the morphology-based classification (ANDERSEN \&

\section{BAILEY 2002).}

In Czech Republic, in total 10 species have thus far been reported (PoulíčKoví et al. 2004), however, most of these reports are at least 20 years old. In this study we identified six species, three reported for the first time in the Czech Republic.

\section{Materials and methods}

Samples of Vaucheria from five localities in the Czech Republic were collected from March to August 2007 (Table 1). Each of the samples had macroscopically visible siphons with a piece of substratum approximately $1.5 \times 1.5 \mathrm{~cm}$. Several samples were observed two or three days after sampling date using light microscopes (Olympus CX-31 and BX-51). Photographs were taken on the Olympus BX-51 with Olympus C-5060 digital camera and Olympus BX51TF with digital camera Olympus DP12. Rieth (1980) and Johnson \& MerRit (2002) were used to identify Vaucheria samples to the species level.

\section{Results}

In total, we found six Vaucheria species in five localities (Table 1).

1) Vaucheria borealis HIRN (Figs 1a, b)

was found in dried-up pool on forest road in the Protected Landscape Area (PLA) Kokořínsko. 
Thalli were 50-85 $\mu \mathrm{m}$ wide. Oogonial dimensions were 61-97 x 94-121 $\mu \mathrm{m}$ and hooked anteridia were 25-35 $\mu \mathrm{m}$ wide. This represents the first report of this species for the Czech Republic.

2) Vaucheria geminata (VAUCHER) DC.

(Figs 1c, d, e)

was found on the margin of an oxbow lake of the upper Lužnice river near by Nová Ves nad Lužnicí in South Bohemia. Vegetative filaments were 40-51 $\mu \mathrm{m}$ wide, oogonial size were 33-56 $\mu \mathrm{m} \times 44-73 \mu \mathrm{m}$. The central hooked antheridia were never longer than lateral oogonia and their width was 16-26 $\mu \mathrm{m}$. Oogonia were mostly in the opposite position. Other record of this species is from the Nesyt pond near Lednice na Moravě town (KomÁRKovÁ et al. 1983).

3) Vaucheria hercyniana RIETH (Figs 2a, b) was collected on a soil surface on the margin of a dry puddle on a forest path near a pond close to the Lednice na Moravě town. The unstalked antheridia and pairwise reproductive structures at the end of filament were the main discriminative features for the identification of this species. Filaments were $38.5-55 \mu \mathrm{m}$ wide. Oogonia were almost spherical with dimensions 88-94 x 88-104 $\mu \mathrm{m}$. Dimensions of the antheridia were $70-73 \mathrm{x}$ 49-54 $\mu \mathrm{m}$. Aplanospores were also observed and they were 68-76 $\mu \mathrm{m}$ wide and 92-95 $\mu \mathrm{m}$ long. This represents the first report of this species from the Czech Republic.

\section{4) Vaucheria sessilis (VAUCHER) DC.}

(Figs 2c, d)

was found in České Středohoří PLA on the river margin Granátka near by Dřevce. Width of the filaments ranged between 50-60 $\mu \mathrm{m}$, oogonial dimensions were 70-80 x 95-115 $\mu \mathrm{m}$ and antheridia 25-30 $\mu \mathrm{m}$ wide. This species was several times reported from different places across the Czech Republic (Jablonec nad Nisou, Stř́ibro, Praha, Rokycany, Rychnov, Tanvald, Velký Osek, Dukovany, Ludkovice, Šumava, Plzeň - PAScher 1903, PoulíčKovÁ et al. 2004).

\section{5) Vaucheria terrestris (VAUCHER) LYNGB.}

(Figs 2e, f)

was found in the same locality as $V$. sessilis. Filaments were 50-55 $\mu \mathrm{m}$ wide, oogonia dimensions were 80-90 × 100-105 $\mu \mathrm{m}$ and antheridia were $25-30 \mu \mathrm{m}$ wide. The population examinated could be classified as $V$. terrestris var. nuoljae SKUJA (RIETH 1980). This species was also reported from Kounov (PoulíčKová et al. 2004), about $30 \mathrm{~km}$ from our locality in Dřevce.

\section{6) Vaucheria woroniniana HEERING}

(Fig. 1f)

was collected from a moist forest track in the surroundings of Mostov village (North Bohemia). Reproductive structures were similar to $V$. geminata, but the terminal antheridium consistently overlapped the two lateral oogonia, which is considered to be crucial discriminating feature of this species (RIETH 1980). The antheridia had two lateral pores. The width of the antheridia was $47-50 \mu \mathrm{m}$. Oogonia were oval without any papilla and their dimensions ranged between $53.5-62 \times 76-82 \mu \mathrm{m}$. The filaments (about $30 \mu \mathrm{m}$ ) were narrower than generative branches (width about $40 \mu \mathrm{m}$ ). The population examinated is the nominate variety, $V$. woroniniana $\mathrm{f}$. woroniniana (RIETH 1980). This represents the first report of this species from the Czech Republic.

Table 1. List of found species and their localities

\begin{tabular}{|c|c|c|c|c|c|}
\hline species & $\begin{array}{l}\text { sampling } \\
\text { date }\end{array}$ & locality & altitude & GPS & \\
\hline V. borealis & 17.3 .2007 & PLA Kokořínsko, Dolní Zimoř & $200 \mathrm{~m}$ a. s. 1. & $50^{\circ} 25^{\circ} 43.957^{\prime \prime} \mathrm{N}$ & $14^{\circ} 30^{`} 33.74^{\prime \prime} \mathrm{E}$ \\
\hline$V$. geminata & 12. 8.2007 & $\begin{array}{l}\text { Nature Reserve Horní Lužnice, } \\
\text { Nová Ves nad Lužnicí }\end{array}$ & 474 m a. s. 1. & $48^{\circ} 49^{`} 14.27^{\circ} \mathrm{N}$ & $14^{\circ} 55^{`} 58.01^{\prime `} \mathrm{E}$ \\
\hline V. hercyniana & 4. 6.2007 & $\begin{array}{l}\text { Lednice na Moravě, Lednice } \\
\text { pond }\end{array}$ & 175 m a. s. 1. & $48^{\circ} 46^{‘} 51.857^{\prime \prime} \mathrm{N}$ & $16^{\circ} 48^{\prime} 13.243^{\prime \prime} \mathrm{E}$ \\
\hline V. sessilis & 1. 5.2007 & $\begin{array}{l}\text { PLA České Středohoří, Dřevce, } \\
\text { river Granátka }\end{array}$ & $600 \mathrm{~m}$ a. s. 1. & $50^{\circ} 29^{‘} 41.097^{\prime} \mathrm{N}$ & $13^{\circ} 52^{`} 35.054^{\prime \prime} \mathrm{E}$ \\
\hline V. terrestris & 1. 5.2007 & $\begin{array}{l}\text { PLA České Středohoří, Dřevce, } \\
\text { river Granátka }\end{array}$ & $600 \mathrm{~m}$ a. s. 1. & $50^{\circ} 29^{\prime} 41.097^{\prime \prime} \mathrm{N}$ & $13^{\circ} 52^{`} 35.054^{\prime \prime} \mathrm{E}$ \\
\hline$V$. woroniniana & 7. 8.2007 & forest near the village Mostov & 420 m a. s. 1. & $50^{\circ} 6^{\circ} 46.243^{\prime \prime N}$ & $12^{\circ} 29^{\circ} 27.667^{\prime \prime E}$ \\
\hline
\end{tabular}




\section{Discussion}

Traditional taxonomy of the genus Vaucheria DC. is based on morphology of their reproductive structures and this morphological classification corresponds with molecular data (ANDERSEN \& BAILEY 2002). The widespread opinion that Vaucheria populations are hard to determine to subgeneric levels in nature is based on findings of sterile filaments. However, for all of the six species in this study, we were able to find the reproductive structures growing in natural conditions. This may not be considered as exception, because e.g., Zelazna-Wieczorek (2002) also reported that spring Vaucheria populations usually have highest frequence of reproductive structures. Cooccurence of several Vaucheria species certainly is a problem for determining which species are present in natural habitats. Caution and careful examination of higher number of specimens from any sample is necessary for correct determination of all present species.

Many species of Vaucheria have cosmopolitan distributions, but a few species have been only once reported in the literature (e.g. $V$. birostris J. Simons in Rieth 1980). Uncommon occurrence of a few species could potentially be caused by their restricted distributions, or their generally low abundance and a small population sizes. Vaucheria sessilis, $V$. borealis, $V$. geminata and $V$. woroniniana belong to frequently reported members of the genus (RIETH 1980). On the other hand, V. terrestris var. nuoljae was so far only reported from Lappland (Abisko) (RIETH 1980). Vaucheria hercyniana was reported only once from Harz Mts. in Germany (RIETH 1980). Thus, our locality near the Lednice na Moravě town is the second locality ever reported for this species.

In several Vaucheria species, substratum preferences have been reported. Vaucheria terrestris typically occurs in subaerophytic mats together with $V$. sessilis and other filamentous algae (e.g. Tribonema, Spirogyra, Mougeotia and Zygnema) on soil surfaces on the margins of rivers and pools (RIETH 1980), which perfectly concurs with our data. Vaucheria hercyniana was reported from ephemeral microhabitats (RIETH 1980) and we also found this species on a wet soil surface on the margin of an ephemeral puddle.

Even if Vaucheria species are widely distributed and they frequently occur in the central European landscape, we still do not have sufficient data on their autecology and biogeography. In this respect, we believe that further floristic research on this ecologically important genus is needed.

\section{Acknownledgement}

We thank RNDr. Jiří Neustupa, PhD. for reading the manuscript and worthful advices and Mgr. Petra Vágnerová for taking the sample from České Středohoř́n.

\section{References}

Andersen, R.A. \& Bailey, J.C. (2002): Phylogenetic analysis of 32 strains of Vaucheria (Xanthophyceae) using the $\mathrm{rbcL}$ gene and its two flanking spacer regions. - Journal of Phycology 38: 583-592.

EtTL, H. \& GärTNER, G. (1995): Syllabus der Boden-, Luft- und Flechtenalgen. - pp. 222-235, Gustav Fischer Verlag, Jena New York.

HouppaGH, K.W. (1930): A taxonomic study of species of the genus Vaucheria collected in California. - American Journal of Botany 17: 329-347.

JOHNSON, L.R. \& MERRIT, R. (2002): Order Vaucheriales. - In John, D.M., WhitTon, B.A. \& Brook, A.J. (eds): The freshwater Algal Flora of British Isles. - pp. 261-270, Cambridge University Press.

KomÁrková, J., Marvan, P., RyČKová, M.A. (1983): Pervičnaja produkcijai rol'vodorostej v litoralnoj zone vodoemov različnogo tipa. - In: RASPOPOV \& HeJNÝ, S. (eds): Gidrobiologičeskije processy. - pp. 91-105, Nauka Lenigradskoe otdelienie, Leningrad.

PAscher, A. (1903): Zur Algenflora des südlichen Bohmerwaldes. - Lotos 23: 161-211.

Potter, D., Saunders, G.W., \& Andersen, R.A. (1997): Phylogenetic Relationships of the Raphidophyceae and Xanthophyceae as Inferred from Nucleotide Sequences of the $18 \mathrm{~S}$ Ribosomal RNA Gene. - American Journal of Botany 84: 966-972.

Poulí̌́KovÁ, A., LhotskÝ, O. \& Dřímalová, D. (2004): Prodromus sinic a řas České republiky. - Czech Phycology 4: 19-33.

RIETH, A. (1980): Xanthophyceae 2. Teil. - In EttL, H., Gerloff, J. \& Heynig, H. (eds): Süsswasserflora von Mitteleuropa, Band 4. - 147 pp., VEB Gustav Fischer Verlag, Jena.

ZelazNa-WieczoreK, J. (2002): Vaucheria species from selected regions in Poland. - Acta Societatis Botanicorum Poloniae 71: 129-139.

(C) Czech Phycological Society

Received February 10, 2008

Accepted April 29, 2008 

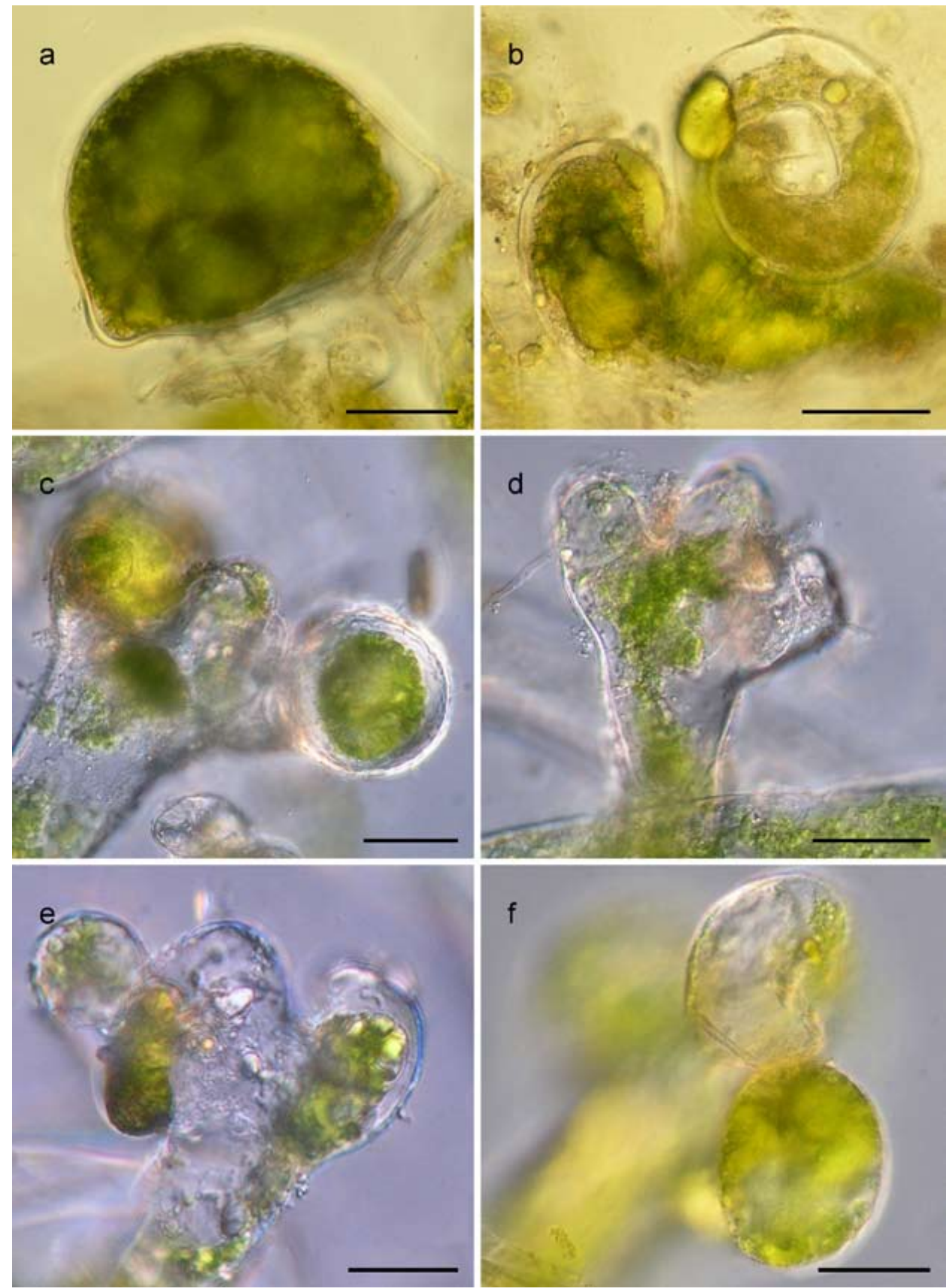

Fig. 1. (a, b) Vaucheria borealis HIRN: (a) oogonium, (b) antheridium and oogonium, scale bar $40 \mu \mathrm{m}$; (c-e) V. geminata (VAUCHER) DC.: (c) generative branch with central antheridium and two oogonia, scale bar $40 \mu \mathrm{m}$, (d) generative branch with central antheridium, scale bar $40 \mu \mathrm{m}$, (e) generative branch with central antheridium and two oogonia, scale bar $25 \mu \mathrm{m}$; (f) $V$. woroniniana HEERING generative branch with central antheridium and two oogonia, scale bar $40 \mu \mathrm{m}$. 

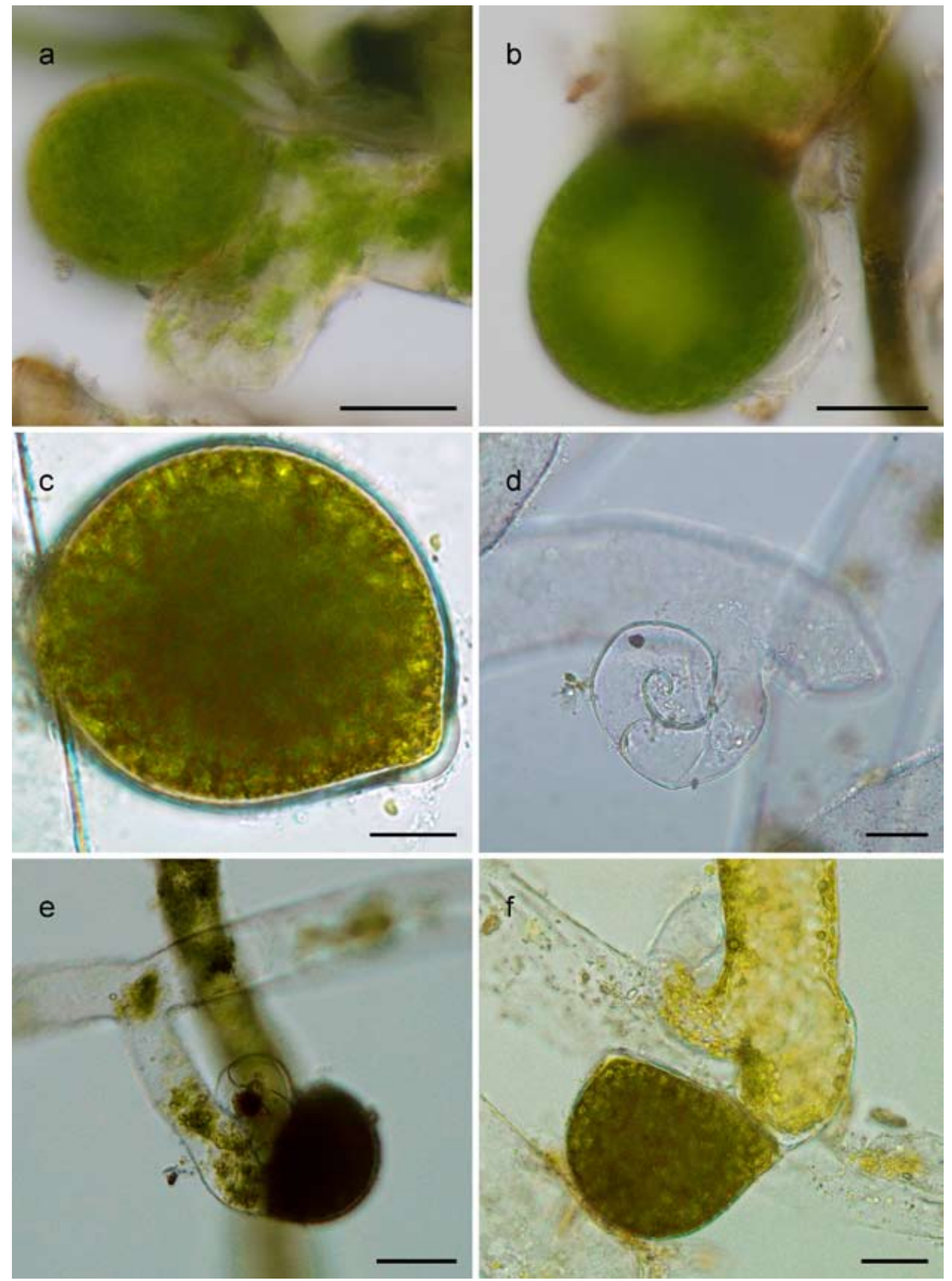

Fig. 2. (a, b) Vaucheria hercyniana RiETH: (a) oogonium and sacks antheridium, (b) oogonium, scale bar $40 \mu \mathrm{m}$; (c, d) V. sessilis (VAUCHER) DC.: (c) oogonium, scale bar $20 \mu \mathrm{m}$, (d) empty antheridium, scale bar $30 \mu \mathrm{m}$; (e, f) Vaucheria terrestris (VAUCHER) LyNGB.: (e) antheridium and oogonium, scale bar $70 \mu \mathrm{m}$, (f) antheridium and oogonium, scale bar $30 \mu \mathrm{m}$. 


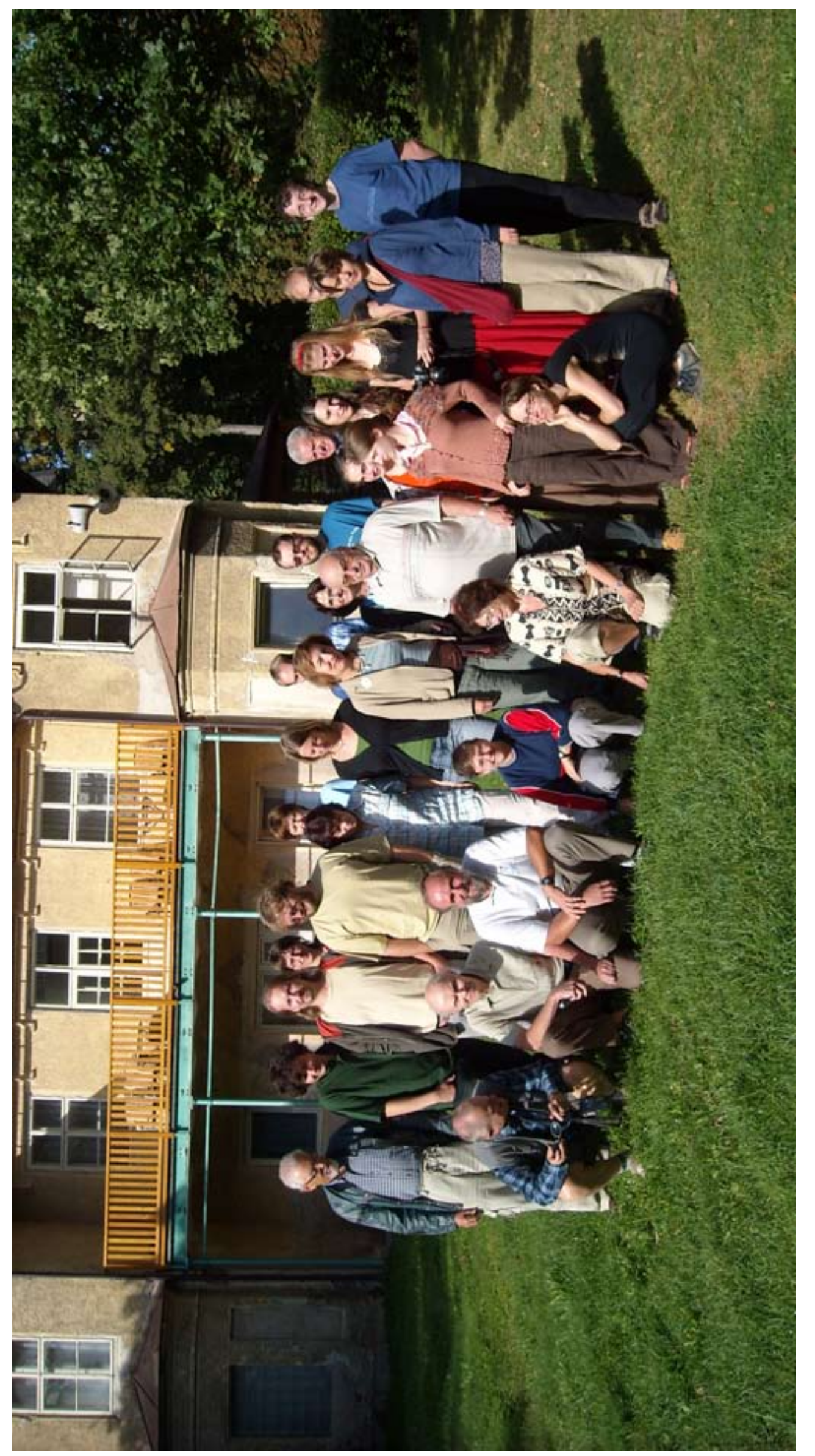

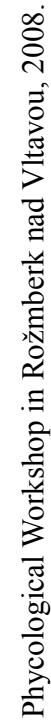

